\title{
OTONOMI DALAM PELAKSANAAN IBADAH KEAGAMAAN
}

\author{
Muhammad Idrus \\ Fakultas Ilmu Agama Islam Universitas Islam Indonesia (UII) Yogyakarta \\ idrus_ibnutarmidi@yaboo.com
}

\begin{abstract}
The aim of this research was to find out (1) the category of worship performing autonomy (2) the difference of worship performing autonomy based on gender and previous school of student; (3) the correlation between age and the degree of worship performing autonomy

The data are collected using questionnaire were involved 100 SMA UII student. The mutli stage sampling that is quota stratified proportional random sampling was used as the sampling technique. Desciptif statistic, $T$ test, product moment correlation from Pearson and Two ways the analaysis of variance are used as the data analysis technique through SPSS for windows program

The result of the several analysis towards the data yields several conclusions (1) most of the SMA UII student were in businessman category of worship performing; (2) there is no difference autonomy of worship performing student based on gender and previous school of SMA UII student; (3) there is no correlation of worship performing between ages and the degree of worship performing category.
\end{abstract}

Keywords: Autonomy, Worship Performing, Religion Education

\begin{abstract}
Abstrak
Penelitian ini bertujuan untuk mengetabui; kategori sikap otonomi siswa dalam menjalankan ibadab keagamaan; perbedaan tingkat otonomi siswa dalam melaksanakan ibadab keagamaan dilibat dari jenis kelaminnya serta asal SLTP siswa; dan korelasi antara usia siswa dengan tingkat otonomi dalam melaksanakan ibadab keagamaan siswa.

Data diambil dengan menggunakan kuesioner terhadap 100 siswa SMU UII. Metode multistage sampling yaitu quota stratified proportional random sampling digunakan untuk menentukan sampel. Teknik pengambilan data menggunakan angket, data dianalisis menggunakan
\end{abstract}


teknik statistik deskriptif, t test, korelasi product moment dari Pearson dan varian dua jalur dengan menggunakan program SPSS for windows. Hasil penelitian menyimpulkan; 1) sebagian besar sikap otonomi subjek termasuk dalam kelompok pedagang, 2) tidak ada perbedaan siswa SMU UII dalam melaksanakan ibadah keagamaan dilihat dari jenis kelaminnya serta asal SLTP siswa, 3) tidak ada korelasi antara usia dengan tingkat otonomi dalam melaksanakan ibadah keagamaan di antara siswa SMU UII.

Kata kunci: Otonomi, Ibadah Keagamaan, Pendidikan Keagamaan

\section{Pendahuluan}

Setiap orang yang beragama harus menjalankan kewajiban-kewajiban ritual yang terkait dengan agamanya. Bagi kaum muslim prosesi keagamaan telah dikenalkan kepada mereka sejak dini, yaitu dengan melantunkan adzan saat mereka dilahirkan. Dilantunkannya adzan dimaksudkan agar sejak dini anak mengenal Tuhannya dan mau melaksanakan perintah-perintah yang ada dalam agamanya. Pada usia 7 tahun, setiap anak dalam keluarga muslim mulai dikenalkan dengan perintah untuk menjalankan shalat, dan pada usia 10 tahun anak sudah mulai diperlakukan keras tatkala tidak mau melaksanakan ibadah shalat.

Pelbagai tahapan tersebut menuntun anak dalam keluarga muslim untuk taat menjalankan perintah agama. Meskipun pada tahapan awal perkembangan keimananannya, ketaatan mereka sebatas menuruti kemauan orang tua mereka, namun diharapkan pada tahapan perkembangan kehidupannya ketaatan tersebut keluar dari lubuk hati mereka. Dalam kajian psikologi, ada tahapan perkembangan kognisi yang di dalamnya juga membahas persoalan ketaatan anak pada aturan yang berlaku. Puncak tahapan tersebut dicapai kurang lebih pada usia 16-17 tahun, yang oleh Kohlberg disebut sebagai tahapan tertinggi dalam perkembangan kognisi anak, yaitu tahap otonomi.

Persoalan otonomi dalam ajaran Islam menjadi dasar bagi manusia untuk melakukan komunikasi dengan Tuhannya secara mesra, tanpa tendensi ataupun rasa ketakutan. Dalam Al-Qur'an, 
otonomi ini diberikan secara tegas kepada manusia seperti terungkap dalam firman Allah SWT di surat al-Baqarah ayat 256; "Tidak ada paksaan untuk memasuki agama (Islam); sesunggubnya telah jelas jalan yang benar daripada jalan yang sesat...."

Pada ayat lain ditegaskan, meskipun sebenarnya Allah dengan ke-Maha-an yang dimilikiNya mampu untuk memaksa manusia untuk beribadah (menyembah diriNya), tetapi hal tersebut tidak dilakukanNya seperti yang diisyaratkan dalam surat Yunus ayat 99 yang artinya; "Dan jikalau Tuhanmu menghendaki, tentulah beriman semua orang yang di muka bumi selurubnya. Apakab kamu (Muhammad) bendak memaksa manusia supaya menjadi orang-orang yang beriman semuanya".

Jika secara cermat disimak, ternyata kedua ayat tersebut bukan hanya memberi peluang kepada manusia untuk memilih siapa "Tuhannya" (dengan simbol agama tertentu yang akan dianutnya), bahkan secara keras menegur Muhammad SAW, agar tidak melakukan pemaksaan kepada manusia. Barangkali seandainya Muhammad SAW memaksakan kehendaknya untuk menjadikan manusia di dunia tunduk (pasrah, Islam), maka mungkin iman yang diperolehnya adalah iman yang tidak jenius dan kualitas rombengan jika meminjam istilah Syafii Maarif untuk menegasi bahwa kualifikasi iman yang demikian memang tidak bermutu sama sekali.

Lebih demokratis lagi, Allah menegaskan dalam Al-Qur'an surat al-Kahfi ayat 29 yang artinya; "...dan katakanlah, kebenaran itu datangnya dari Tubanmu, maka barangsiapa yang ingin (beriman) bendaklan ia beriman, dan barangsiapa yang ingin (kafir) biarlah ia kafir..." Dengan begitu jelas bahwa kebebasan beragama adalah sebuah 'kehormatan' bagi manusia dari Tuhan, karena Tuhan mengakui hak manusia untuk memilih sendiri jalannya (Madjid, 1994: 219).

Lebih jauh lagi, adanya peluang pilihan bebas yang diperoleh manusia mentengarai esensi keberadaan manusia di muka bumi. Seperti diungkap Maarif (1995: 15) bahwa manusia menjadi manusia karena kepadanya diberi hukuman dan pilihan moral untuk diterima dengan penuh kesadaran atau ditolaknya dengan penuh kesadaran pula. Tentu harus disadari, bahwa kebebasan memilih tersebut 
sebatas kemampuan (istitha'ah) yang memang telah diberikan Allah kepada manusia, sebagai syarat kemanusiaannya. Pada intinya kewenangan untuk memilih baik sesuatu yang baik ataupun yang buruk dengan penuh kesadaran atas konsekuensi pilihannya menjadi esensi keberadaan manusia.

Kesadaran atas satu perbuatan harus ditaati atau harus dilakukan tanpa ada unsur yang mensyaratinya (pamrih) merupakan titik tertinggi dalam perkembangan keagamaan seseorang. Jika merujuk pada tahapan perkembangan moral yang diajukan Lawrence Kohlberg (1976: 32), kondisi tersebut dapat dikelompokkan dalam tahapan postconventional level. Dalam istilah yang berbeda, filsuf Imanuel Kant, mengistilahkannya sebagai otonomi (Tjahyadi, 1991: 89). Berdasarkan paparan di atas, tentunya para siswa SMU yang berusia antara 15-19 tahun telah menerima pengetahuan agama lebih dari sekadar cukup untuk menjalankan perintah-perintah minimum dalam agama Islam. Dengan sendirinya, mereka memiliki tingkat kesadaran untuk menjalankan ibadah agamanya masuk dalam kategori baik.

Mentengarai kondisi yang terjadi pada banyak kelompok pelajar, tampaknya perlu juga dilihat apakah memang mereka telah memiliki otonomi dalam menjalankan ibadah agama mereka. Hingga saat ini penelitian yang mengungkap hal tersebut tampaknya belum ada. Untuk itu penelitian ini akan mengungkap tingkat otonomi keagamaan siswa SMU, untuk lokasi ditentukan di SMU UII. Pemilihan ini berdasarkan letak georgrafis SMA UII berada pada tepat di daerah perbatasan antara Kotamadya Yogyakarta dan Kabupaten Bantul yang tentunya secara spesifik memiliki kekhasan dalam bersikap sebagai kelompok sub-urban dan perkotaan. Secara praktis, bagi pihak sekolah SMU UII, dapat menjadi balikan bagi perumusan model ideal pendidikan sesuai dengan kaidah agama Islam.

\section{Konsep Otonomi dalam Pelaksanaan Ibadah Keagamaan}

Dengan menggunakan model tahapan yang diajukan oleh Jean Piaget, Lawrence Kohlberg (1976) mengajukan teori perkembangan moral, yang memposisikan otonomi menempati posisi tertinggi dalam rangkaian perkembangkan moral seorang anak. Pada fase tersebut 
seseorang memiliki kebebasan untuk menentukan satu pilihan moral sesuai dengan kehendak yang dimilikinya. Pilihan tersebut tentunya tidak terbatas dalam hal tertentu, demikian juga dalam memilih agama.

Merujuk pada konsep ajaran Islam, persoalan otonomi dalam ajaran Islam menjadi dasar bagi manusia untuk melakukan komunikasi dengan Tuhannya secara mesra, tanpa tendensi ataupun rasa ketakutan. Tuhan secara jelas mengungkap tentang fenomena otonomi ini dalam beberapa firmanNya. Pada penelitian ini yang dimaksud dengan otonomi dalam pelaksanaan ibadah keagamaan adalah, tumbuhnya kesadaran pada diri seseorang bahwa dirinya memiliki kewajiban moral untuk melaksanakan syariat agama tanpa adanya pengharapan imbalan (pahala) atas apa yang dilakukannya, serta bukan karena keharusan yang tercantum dalam kitab suci atau hadits nabi. Pada sisi lain jika dia meninggalkan larangan agama bukan disebabkan ketakutan akan adanya ancaman siksa yang akan dihadapi jika hal tersebut dilakukannya, atau atas paksaan dari manapun. Secara singkatnya dapat dinyatakan apapun perbuatan yang dilakukannya, maka hal itu dilakukan atas dasar keikhlasan, tidak ada pamrih atau ketergantungan atas sesuatu.

\section{Dimensi Praktek Keagamaan}

Berkaitan dengan fokus penelitian, maka perlu dipaparkan beberapa hal yang berkaitan dengan unsur pelaksanaan praktek ibadah keagamaan. Stark dan Glock (dalam Robertson, 1988: 295-299) dalam tulisannya mengajukan lima dimensi keagamaan yang terdiri dari dimensi keyakinan, praktek, pengalaman, pengetahuan, dan konsekuensi-konsekuensi. Berikut ini akan dipaparkan masing-masing dimensi tersebut.

Dimensi pertama adalah dimensi keyakinan. Dalam agama Islam, dimensi keyakinan diwujudkan dalam pengakuan (syahadat) yang diwujudkan dengan membaca dua kalimah syahadat (syahadatain). Dimensi keyakinan menuntut dilakukannya praktek peribadatan yang sesuai dengan nilai-nilai Islam. Dimensi kedua, adalah dimensi praktek atau ritualistik agama. Dimensi praktek dalam agama Islam dapat seperti menjalankan ibadah shalat, puasa zakat, 
ibadah haji ataupun praktek muamalah lainnya. Tentu saja unsur ketaatan dalam menjalankan aktivitas tersebut memang diharapkan muncul dalam diri setiap orang yang menjalankannya.Dimensi berikutnya adalah dimensi pengalaman. Dimensi ini berkaitan dengan berbagai pengalaman kegamaan yang dimiliki oleh seseorang dalam proses menjalani agama yang dianutnya. Dimensi keempat adalah dimensi pengetahuan agama. Dimensi ini secara erat terkait dengan dimensi keyakinan, karena salah satu syarat yang harus dimiliki bagi penerimaan satu ajaran, adalah dimilikinya seperangkat pengetahuan tentang ajaran agama yang bersangkutan. Hal ini mendukung tesis yang pernah diajukan Albert Einstein, bahwa science without religion is blind and religion without science is limp. Selanjutnya dimensi terakhir, konsekuensi. Dimensi ini mengacu pada identifikasi akibat-akibat keyakinan agama, praktek, pengalaman dan pengetahuan seseorang.

Dari paparan di muka, maka objek kajian dalam dimensi keberagamaan dapat dilihat dari sisi keyakinan, praktek, pengalaman, pengetahuan agama serta konsekuensi. Selanjutnya berkaitan dengan konteks penelitian ini, peneliti membatasi pada perilaku subjek penelitian dalam dimensi keyakinan, praktek, pengetahuan, serta konsekuensi. Secara lebih terfokus kajian tersebut akan melihat otonomi siswa dalam praktek peribadatan agama, praktek shalat, puasa, serta aktivitas anjuran untuk berbuat baik pada sesama. Selain itu juga akan dilihat sikap subjek atas larangan yang ditetapkan agama, seperti larangan berzina, mabuk-mabukan, berjudi, menipu, serta beberapa perilaku larangan lain dalam hubungannya dengan sesama manusia (mu'amalab).

Salah satu cara termudah untuk mengungkap fenomena otonomi keagamaan yang dimiliki seseorang adalah dengan melihat perilaku ataupun sikap keagamaan yang mereka tunjukkan. Tentang sikap keagaaman ini, menarik untuk menyimak paparan yang diajukan Shihab (1994: 67) yang mengelompokkan menjadi 3, yaitu; 1) Perilaku pedagang, yakni melakukan sesuatu demi memperoleh imbalan yang lebih menyenangkan dan lebih baik dari yang telah diberikannya. Gambaran perilaku "pedagang", yang mengharapkan adanya balasan yang lebih baik atas perbuatan yang dilakukannya, atau ketakutan terhadap azab, menandakan rendahnya tingkat 
otonomi dalam pelaksanaan keagamaan yang dimiliki seseorang; 2) Sikap sang budak atau buruh, yaitu jika seseorang yang beribadah karena dorongan takut siksa neraka pada hakekatnya memperagakan sikap budak atau sikap buruh terhadap Tuhannya; 3) Sikap sang arif, yaitu seseorang beribadah karena dia menyadari betapa besar anugerah yang telah diperolehnya dan betapa bijaksananya Tuhan dalam segala ketetapan dan perbuatannya. Kesadaran ini mendorong sang arif untuk beribadah dan melakukan segala aktivitasnya sebagai "balas jasa", bukan karena mengharap imbalan surgawi atau karena takut neraka. Dari kesadaran akan kebijaksanaan Tuhan, ia yakin di mana pun ia ditempatkan, pasti hal itu merupakan hal yang terbaik baginya. Sikap bijaksana Tuhan yang tercermin dengan rasa keadilan Tuhan menjadikannya sebagai seorang abid (ahli ibadah) yang tidak lagi berpikir apa yang akan didapatnya setelah ibadah itu dilakukannya. Perilaku sang arif dalam beribadah merupakan gambaran seseorang yang memiliki otonomi keagamaan yang baik.

Kohlberg (1995) dalam penelitiannya, mengenai dilema moral yang dihadapi anak, memberi beberapa kesimpulan. Pertama, keputusan moral bukanlah soal perasaan (nilai), melainkan selalu mengandung suatu tafsiran kognitif terhadap dilema moral dan bersifat konstruktif yang aktif terhadap titik pandang masing-masing partisipan dan kelompok yang terlibat, sambil mempertimbangkan segala macam tuntutan, hak, kewajiban dan keterlibatan setiap pribadi (kelompok) terhadap yang baik dan yang adil. Kesemuanya merupakan tindakan kognitif. Kedua, terdapat sejumlah pertimbangan moral yang sesuai dengan pendapat yang diajukan oleh Piaget, yaitu dengan adanya ciri pola fikiran formal yang ada dalam diri anak. Ketiga, membenarkan pendapat yang diajukan Piaget bahwa usia 16 tahun merupakan usia tertinggi remaja dalam pertimbangan moral. Menarik untuk disikapi adalah batasan usia 16 tahun yang bagi masyrakat barat telah dianggap memiliki otonomi yang baik. Tentu saja batasan usia ini akan menjadi relatif berbeda tatkala terminologi budaya ikut serta dalam pembahasannya. Setidaknya dengan menggunakan pendekatan lintas budaya penelitian tentang batasan usia ini akan menjadi menarik. 
Untuk kasus dengan mengambil setting di Indonesia, penelitian tentang moralitas politik pernah dilakukan oleh Wahyono (1995) dalam upayanya untuk mendapatkan gambaran tentang kualitas moral dan perilaku moral politik, lingkungan keluarga, sekolah dan pergaulan siswa dengan kelompok sebaya. Dengan menggunakan pendekatan kuantitatif penelitian Wahyono tersebut memberi kesimpulan bahwa tingkat penalaran siswa di lokasi penelitian cukup tinggi.

Dalam tesisnya, Idrus (1998) mengambil tema yang hampir senada dengan mahasiswa Fakultas Tarbiyah UII sebagai respondennya. Dengan menggunakan pendekatan kualitatif Idrus (1998) menyatakan bahwa mahasiswa Fakultas Tarbiyah UII ternyata belum memiliki tingkat otonomi moral yang baik, artinya mereka masih dalam teraf heteronomi. Temuan lain yang diperoleh Idrus adalah bahwa dalam beragama ternyata mahasiswa cenderung masuk dalam katagori sikap pedagang, yang selalu menghitung untung rugi dalam pelaksanaan peribadatannya. Kedua penelitian di atas, ternyata memiliki simpulan yang bertolak belakang. Pada penelitian Wahyono mungkin cenderung mendukung apa yang diajukan oleh Kohlberg, sementara penelitian Idrus menolak pendapat di atas. Lebih lanjut tentang penelitian yang bertemakan agama dapat dilihat berikut ini.

Berkaitan dengan penelitian keagamaan, 'Abdul Mun'im 'Abdul 'Aziz al-Maligy (dalam Nizar, 1992) meneliti anak-anak dan remaja Mesir tentang kepercayaan mereka terhadap Allah dan sifatsifatnya, surga dan neraka, kematian, malaikat, syetan dan beberapa hal lain yang berkaitan dengan persoalan keagamaan. Hasil penelitian al-Maligy menemukan bahwa pemahaman tentang Allah mulai dari masa anak-anak sampai remaja berproses dalam tiga tahap. Tahap pertama, pada saat anak-anak mulai berfikir tentang Allah ia membayangkan Allah sebagai tokoh bapak dengan sifatsifat kebapakannya. Kedua saat mulai beranjak remaja saat ia merasakan dorongan-dorongan seks akibat perkembangan dalam dirinya. Padahal di sisi lain dorongan tersebut bertentangan dengan nilai-nilai yang ada baik dalam agama maupun dalam masyarakat, - sebagaimana dipahami latar belakang budaya dan agama responden adalah Islam dengan kultur timur yang kuat-. Pada 
akhirnya hal tersebut memunculkan rasa berdosa, dan dia takut akan mendapa azab neraka. Pada posisi tersebut dia membutuhkan Allah untuk membantunya melepaskan diri dari semua itu. Pada tahapan ini keimanan pada Allah diperlukan untuk mencari sandaran dan bantuan moral.

Tahap ketiga, sesuai dengan masa perkembangannya maka pemahaman tentang dzat Allah muncul semakin baik. Pada tahap ini pemikirannya mulai ke arah filosofis dengan mengkaitkan pemikiran tentang Allah dengan alam ciptaanNya. Tahap ini mulai terlihat pada akhir masa remaja.

Dari simpulan di atas, ternyata proses penyadaran remaja akan adanya Allah berproses mulai dari Allah sebagai figur bapak, yang dapat dimaknai sebagai figur pelindung. Kemudian Allah berposisi sebagai figur penolong atas segala kesulitan yang sedang dihadapinya, dan baru pada masa akhir eksistensi adanya Allah disadari secara baik. Jika merujuk pada batasan usia, maka usia akhir remaja diperkirakan antara 18-20 tahun. Selain ketiga kesimpulan tersebut, al-Maligy juga mengungkap tentang sikap remaja terhadap agama yang secara garis besar dituangkan dalam tabel 1 yang penulis kutip berikut;

Tabel 1.

sikap Remaja Terhadap Agama

\begin{tabular}{lcccc}
\hline \multicolumn{1}{c}{ Sikap Beragama } & \multicolumn{2}{c}{ Remaja Putra } & \multicolumn{2}{c}{ Remaja Putri } \\
& $\mathrm{f}$ & $\%$ & $\mathrm{f}$ & $\%$ \\
\hline percaya ikut-ikutan & 50 & 50 & 43 & 61,5 \\
percaya dengan kesadaran & 25 & 25 & 18 & 25,7 \\
ragu-ragu & 24 & 24 & 9 & 12,8 \\
tidak percaya & 1 & 1 & 0 & 0 \\
\multicolumn{1}{c}{ Jumlah } & 100 & 100 & 70 & 100 \\
\hline
\end{tabular}

(Sumber Nizar, 1992)

Dari tabel 1 tersebut tampak ada variasi sikap remaja terhadap agama Hal yang menarik tampaknya persentase sikap remaja yang percaya karena ikut-ikutan (taklid) untuk masing-masing kelompok 
subjek penelitian menduduki pada peringkat pertama. Al-Maligy mengidentifikasikan bahwa tingginya sikap ikut-ikutan pada diri remaja putri lebih disebabkan model pendidikan di Mesir yang menuntut anak wanita untuk patuh pada keluarga, khususnya orangtua.

Selanjutnya dalam penelitiannya, al-Maligy juga mengungkap fenomena keraguan remaja terhadap agama dengan melihat usia remaja. Hasil penelitiannya menunjukkan keraguan remaja terhadap agama meningkat pada masa awal remaja, dan kembali menurun pada periode akhir remaja. Fenomena ini menurut al-Maligy (dalam Nizar, 1992) disebabkan terjadinya perkembangan pemikiran dalam diri remaja. Pada periode akhir tersebut, remaja mulai berpikir secara mendalam tentang Allah dan sifat-sifatnya. Mereka mencoba menghubungkan antara sifat qudrah, iradah dan sifat keadilan yang dimiliki Allah. Remaja melihat bahwa qudrah dan iradah Allah mendominasi kemerdekaan manusia untuk memilih yang pada hakekatnya berlawanan dengan sifat keadilan Allah.

Selanjutnya masih dalam topik yang sama, ternyata pada usia 21 tahun persentase mereka yang memiliki sikap ragu-ragu terhadap agama menurun. Rupanya pada usia tersebut remaja berusaha untuk menemukan identitas diri sendiri dalam menjalankan agama yang dipeluknya. Saat itu remaja mencoba untuk mempelajari agama berdasarkan pemahaman intelektual yang dimilikinya serta tidak menerima begitu saja faham yang diberikan atau diajarkan kepada mereka.

Tampaknya Maligy melihat pada usia 21 tahun tersebut, anak telah memiliki satu peluang untuk berbuat sesuatu secara mandiri. Keinginan anak untuk menerima agama tanpa adanya pengaruh orang lain, jelas menunjukkan tingkat otonomi keagamaan yang dimilikinya. Dengan begitu, dapat dinyatakan bahwa berkembangnya usia anak, akan semakin meningkatkan tingkat otonomi keagamaan anak dan kematangan pemahaman anak dalam beragama. Hasil penelitian tersebut secara tidak langsung merekomendasikan bahwa usia 21 tahun tampaknya sebagai awal kematangan anak dalam menerima agama.

Dari beberapa penelitian yang telah dilakukan para peneliti terdahulu, ternyata persoalan otonomi khususnya otonomi dalam 
hal peribadatan keagamaan belum diteliti secara mendalam. Mengingat pentingnya kedudukan otonomi dalam pelaksanaan ibadah keagamaan dalam konteks hubungan peribadatan manusia dengan tuhannya, maka akan sangat menarik untuk mengkaji persoalan tersebut secara lebih mendalam.

\section{Kerangka Berpikir dan Pengajuan Hipotesis}

Adanya temuan para peneliti terdahulu yang menyatakan bahwa tingkat otonomi akan mencapai puncaknya pada usia 16 tahun (temuan dari Kohlberg) menjadi satu fenomena menarik untuk dilakukan kaji ulang. Sebab pada dasarnya, adanya perbedaan pola asuh antara budaya barat dan budaya timur mungkin pula akan menyebabkan perbedaan otonomi yang dimiliki seorang anak.

Seperti dipahami, penelitian Kohlber dengan setting penelitian barat dengan budaya demokrasi tumbuh subur memungkinkan seorang anak untuk tumbuh dan berkembang sesuai dengan yang seharusnya. Artinya merujuk pada tahapan perkembangan moral yang diajukan Piaget ataupun Kohlberg, usia 16 tahun mungkin menjadi puncak awal tingkat otonomi seorang anak. Sementara penelitian yang saat ini dilakukan mengambil setting budaya timur, dimana budaya demokrasi belum seluruhnya masuk pada tatanan kehidupan seorang anak. Dengan sendirinya, ada fase-fase tertentu saat anak harus menerima pendapat dari orang lain, tanpa dia diberi kesempatan untuk menolaknya, atau pada sisi lain, dia harus melakukan sesuatu aktivitas padahal tidak didasari atas rasa kesadaran dalam dirinya.

Selain itu, penelitian terdahulu juga menyimpulkan adanya korelasi antara usia dengan tingkat otonomi seseorang. Dengan setting budaya yang berbeda penelitian tersebut dapat direplikasi. Penelitian ini akan melihat korelasi antara usia siswa dengan tingkat otonominya dalam menjalankan ibadah keagamaan. Perbedaan jenis kelamin pada penelitian terdahulu dianggap memiliki kontribusi dalam ketercapaian otonomi. Pada penelitian ini akan direplikasi dengan asumsi bahwa budaya yang berbeda akan memiliki peluang hasil yang berbeda. Dengan kerangka berpikir demikian, maka seluruh rangkaian persoalan yang diajukan dihipotesiskan 
sebagai berikut; 1) Tidak ada perbedaan tingkat otonomi keagamaan siswa SMU UII ditinjau dari jenis kelaminnya; 2) Tidak ada perbedaan tingkat otonomi keagamaan siswa SMU UII ditinjau dari asal SLTP siswa; 3) Ada korelasi antara usia siswa dengan tingkat otonomi siswa SMU UII

\section{Metode Penelitian}

Pendekatan yang digunakan dalam penelitian ini adalah expost facto, dan eksploratorif. Populasi penelitian ini adalah seluruh siswa SMU UII, sampel akan diambil dengan model multistage sampling, yaitu quota stratified proportional random sampling. Jumlah proporsi yang ditentukan adalah sebanyak $25 \%$ dari populasi. Mengingat kelas III saat ini sedang dalam persiapan ujian akhir (UN) pihak sekolah hanya mengijinkan untuk pengambilan data dilakukan pada siswa kelas I, dan II.

Dengan pertimbangan jumlah responden yang dianggap dapat mewakili, maka jumlah responden ditetapkan secara quota sampling, yaitu sebanyak 100 orang. Jumlah ini lebih dari jumlah proporsi $25 \%$ yang telah ditetapkan semula. Namun demikian dalam pelaksanaan analisis data ternyata ada 2 (dua) data yang cacat dan tidak mungkin dianalisis.

Data akan diambil dengan menggunakan angket yang dikembangkan dari konsep teoritik yang diajukan. Model angket menggunakan model pilihan dengan 3 alternatif. Alternatif pilihan didasarkan atas konsep otonomi sebagaimana diajukan Shihab, yaitu tidak adanya otonomi dan adanya otonomi. Konsep ketidaadaan otonomi jika merujuk pada konsep teoritik yang diajukan mengacu pada model model sikap kepatuhan seorang hamba yang melaksanakan sesuatu atas adanya perintah, dan model pelaksanaan perintah ala pedagang yang melaksanakan sesuatu atas pamrih tertentu. Konsep otonomi jika merujuk pada konsep teoritik mengacu pada konsep kepatuhan sang arif.

Penyusunan angket berdasar pada teoritik yang dideskripsikan di muka, dan dibuat berdasar pada kisi-kisi berikut ini; 
Tabel 3

Kisi-kisi Angket

\begin{tabular}{cl}
\hline Sub variabel & \multicolumn{1}{c}{ Indikator } \\
\hline Praktek ritual & 1. Keinginan melaksanakan Satu perintah \\
& 2. Keingingan untuk menghindari larangan \\
& 3. Berhubungan dengan sesame \\
Pengetahuan & 4. Menambah pengetahuan \\
& 5. Mengajarkan agama \\
Konsekuensi & 6. Harapan atas pelaksanaan perintah dan larangan \\
\hline
\end{tabular}

Untuk menganalisis data dalam penelitian ini akan digunakan teknik statistik deskriptif untuk mengkategorikan sikap otonomi siswa dan statistik inferensial t test untuk menganalisis hipotesis nomor 1, sedangkan $\mathrm{n}$ hipotesis nomor 2, hipotesis 3 akan dilakukan dengan menggunakan korelasi product moment dari Pearson dan analisis varian dua jalur (Popham Popham, J.W. and Sirotnik, K.A. 1971).

Untuk pengkatagorisasian otonomi dalam pelaksanaan ibadah dengan menggunakan 3 model yaitu (1) otonomi dengan model budak, (2) otonomi model pedagang, (3) otonomi model sang arif, sebagaimana diajukan Shihab. Dengan model pengkatagorian tersebut ternyata mereka yang memiliki otonomi dengan model budak sebanyak 6 orang $(6,1 \%)$, model pedagang sebanyak 59 orang $(60,2 \%)$, dan mereka yang termasuk dalam kelompok arif sebanyak 33 orang $(33,7 \%)$.

Selanjutnya dengan menggunakan analisis crosstabs (tabulasi silang), pengelompokkan responden tentang model otonomi yang mereka miliki dapat dilihat dari sisi asal SLTP siswa yang bersangkutan. Dari hasil penelitian ternyata yang termasuk dalam katagori "sang arif" persentase tertinggi berasal dari kelompok pondok pesantren yaitu sebesar 37,5\%, kelompok kedua berasal dari kelompok M.Ts sebesar 35,1\% dan sisanya berasal dari kelompok SLTP Umum sebesar 32,89\%.

Uji Hipotesis Penelitian menggunakan formula t test diperoleh harga sebagai berikut, dengan model pooled variance estimate harga t diperoleh sebesar -1,29, sedangkan dengan menggunakan model 
Separate Variance Estimate diperoleh harga t sebesar -1,31. Kedua harga t tersebut tidak signifikan pada taraf signifikansi $5 \%$. Dengan begitu dapat disimpulkan bahwa, tidak ada perbedaan tingkat otonomi siswa dalam melaksankan ibadah keagamaan ditinjau dari jenis kelamin siswa SMU.

Untuk menguji hipotesis kedua dilakukan dengan menggunakan teknik analisis varian dua jalur. Dari hasil analisis diperoleh harga main effect sebesar 1,556, dan ternyata harga ini tidak signifikan pada taraf signifikansi $5 \%$. Mengingat hasil interaksi tersebut, maka uji hipotesis tidak dilanjutkan dengan antar jalur. Dengan begitu dapat disimpulkan bahwa tidak ada perbedaan tingkat otonomi siswa dalam melaksanakan kegiatan ibadah keagamaan.

Untuk menganalisis hipotesis ke-tiga digunakan formula korelasi product moment dari Pearson. Dari hasil analisis diperoleh harga korelasi antara usia siswa dengan tingkat otonomi siswa SMU UII dalam melaksanakan ibadah keagamaan yaitu sebesar 0.0060. Dari hasil tersebut maka disimpulkan tidak ada korelasi antara usia siswa dengan tingkat otonomi siswa SMU UII dalam melaksanakan ibadah keagamaan.

\section{Analisis}

Dari paparan hasil penelitian ada beberapa hal yang patut diulas untuk mempertegas hasil penelitian. Pertama, secara katagoris seluruh responden dapat diposisikan pada katagoris yang telah dibuat, yaitu model otonomi budak, model otonomi pedagang, dan otonomi sang arif. Kecenderungan yang ada, ternyata sekitar 59 orang $(60,2 \%)$ siswa SMU UII yang dijadikan responden dalam penelitian ini memiliki otonomi dengan model pedagang.

Seperti dipahami model otonomi pedagang lebih berorientasi akan dampak keuntungan jika peribadatan tersebut dilaksanakan, atau kerugian (baik berupa ancaman siksa) jika ibadah tersebut tidak dijalaninya. Kecenderungan ini mungkin menjadi kecenderungan mayoritas di banyak populasi, sebab pada dasarnya semua orang menginginkan hidup bahagia baik di dunia maupun di akhirat. Kondisi ini akan menjadikan pola pikir mereka untuk melakukan atau tidak melakukan satu perbuatan, tentu saja dengan 
pertimbangan perbuatan tersebut berdampak bagi dirinya (baik menguntungkan ataupun tidak menguntungkan).

Jika kondisi ini ditarik lebih jauh pada ajaran dasar yang diterima oleh setiap pemeluk agama, tampaknya model pengajaran pendidikan keagamaan memang mengarahkan siswa untuk melakukan atau tidak melakukan sesuatu karena adanya janji baik berupa ancaman ataupun pahala. Meski demikian, hal ini memang mengisyaratkan bahwa siswa belum sampai pada tingkat otonomi dalam pelaksanaan peribadatannya.

Selain itu, jika dilihat dari sisi katagoris mereka yang menduduki posisi otonomi dengan model budak sebanyak 6 orang $(6,1 \%)$. Satu jumlah yang relatif kecil, jika dibandingkan dengan kecenderungan yang terjadi. Hal ini menunjukkan hanya ada sekitar 6,1 \% yang melaksanakan ibadah dengan keterpaksaan. Tentunya hasil ini secara tidak langsung mengisyaratkan bahwa aktivitas keagamaan yang dilaksanakan di lokasi penelitian — hingga penelitian ini dilaksanakan - dapat dikatagorikan cukup baik. Meski hal tersebut perlu penelitian lanjutan, namun setidaknya hasil ini mengindikasikan mereka yang beribadah karena terpaksa hanya sedikit.

Hal lain yang mendukung sinyalemen di atas adalah, hasil penelitian ini menunjukkan sebanyak 33 orang $(33,7 \%)$ termasuk dalam kelompok "sang arif". Kelompok ini adalah mereka yang memiliki kesadaran bahwa ibadah tidak selamanya harus dikaitkan dengan persoalan pahala ataupun dosa manakala hal itu tidak dilakukan, namun sebagai refleksi kesadaran bahwa sebagai manusia dirinya wajib berterima kasih atas segala hal yang telah diberikan Allah kepada mereka. Hal ini cukup menggembirakan jika dikaitkan dengan kondisi pembinaan generasi muda saat ini, yang harus diakui mengalami kesulitan dengan semakin maraknya peredaran obat-obatan.

Adanya kesadaran peribadahan tersebut akan membawa dampak positif atas model pembinaan yang sedang dilaksanakan. Kondisi-kondisi di atas secara tidak langsung mengisyaratkan betapa model pembinaan keagamaan yang diterapkan di SMU UII saat ini cukup kondusif untuk pembentukan sikap mental dan otonomi yang baik, sehingga perlu dipertahankan dan untuk selanjutnya 
ditingkatkan. Meski juga harus diakui bahwa masih perlu dipertanyakan kontribusi langsung model pembinaan yang diterapkan dengan tingkat otonomi siswa dalam menjalankan ibadah keagamaan, dan tentu saja hal ini perlu dilakukan penelitian lanjutan.

Dalam deskriptif tampak ada perbedaan tingkat otonomi siswa SMU UII jika ditinjau dari sisi jenis kelamin dan latar belakang pendidikan mereka sebelumnya (asal SLTP). Sebagaimana tercantum dalam tabel 5 di muka, dari asal SLTP ternyata mereka yang berasal dari pondok pesantren secara persentase menduduki posisi tertinggi dalam katagori otonomi sang arif, yaitu sebesar 37,5\%, kelompok kedua berasal dari kelompok M.Ts sebesar 35,1\% dan sisanya berasal dari kelompok SLTP Umum sebesar 32,89\%.

Selintas paradigma yang dapat dibangun adalah mereka yang berasal dari pondok pesantren memang telah memahami beberapa hal dasar mengenai peribadatan termasuk di dalamnya mengapa mereka harus melakukannya. Artinya jika secara katagoris kelompok ini tidak ada yang memiliki otonomi model budak memang sudah seharusnya, mengingat pengertian dasar peribadatan telah mereka terima sejak mereka masuk pondok pesantren.

Tentunya hal itu berbeda dengan mereka yang berasal dari Madrasah Tsanawiyah sekalipun, apalagi mereka yang berasal dari SLTP umum. Perbedaan tersebut menjadi logis tatkala latar belakang tersebut terkait dengan pemahaman keagamaan mereka, sehingga secara logis perbedaan itu wajar. Meski demikian, hal tersebut perlu pengujian agar perbedaan itu memang perbedaan senyatanya dan bukan karena perbedaan sampel semata.

Untuk menguji hipotesis ini digunakan teknik analisis varian dua jalur. Dari hasil analisis ternyata diperoleh harga main effect sebesar 1,556, dan ternyata harga ini tidak signifikan pada taraf signifikansi $5 \%$. Dengan begitu hipotesis yang diajukan tidak terbukti. Artinya, jika pada paparan deskriftif tampak ada perbedaan tingkat otonomi ditinjau dari latar belakang pendidikan mereka di SLTP-nya, maka tampaknya secara statistik tidak terjadi hal itu. Dengan begitu, dapat dimaknai darimanapun asalnya sekolah siswa (sekolahnya di SLTP) tidak mempengaruhi tingkat otonomi meraka dalam beribadah. Jika dalam kajian pendidikan ada sinyalemen 
bahwa miliu akan berpengaruh terhadap perkembangan seseorang, tampaknya pengaruh tersebut tidak general dan hanya bersifat individual.

Selain hal di atas, penelitian ini juga ingin mengungkap tentang ada tidaknya tingkat otonomi siswa dalam beribadah keagamaan jika ditinjau dari jenis kelamin respondennya. Pada paparan penelitian terdahulu ada peneliti yang tampaknya melihat ada perbedaan persoalan keagamaan yang dirasakan remaja putra dengan remaja putri, setidaknya penelitian yang dilakukan Maligy menyatakan yang demikian. Hasil perhitungan yang dilakukan dalam penelitian ini ternyata tidak mengindikasikan hal itu. Seperti diajukan dalam bab terdahulu, salah satu hipotesis yang ingin diuji adalah ada tidaknya perbedaan tingkat otonomi keagamaan jika ditinjau dari jenis kelamin siswa.

Paparan secara deskriptif tampaknya cenderung menyatakan ada perbedaan tingkat otonomi jika ditinjau dari jenis kelamin siswa. Untuk itu pengujian secara statistik dilakukan dengan menggunakan formula t test. Dari hasil perhitungan dengan formula tersebut baik dengan menggunakan pooled model ataupun separate model, ternyata angka-angka yang dihasilkan di bawah harga tabel. Artinya adalah adanya hipotesis bahwa ada perbedaan tingkat otonomi siswa dalam menjalankan ibadah keagamaan tidak terbukti, sehingga penelitian ini menolak hipotesis alternatif yang diajukan.

Dengan begitu dapat dinyatakan bahwa persoalan otonomi siswa dalam menjalankan ibadah keagamaan tidak tergantung pada jenis kelamin siswa. Tentu saja secara psikologis dapat dibuktikan bahwa sebenarnya tingkat perkembangan ataupun kematangan antara lelaki dan perempuan relatif sama, adanya perbedaan di antara mereka tampaknya lebih bersifat individual, dan tentu saja hal ini tidak dapat digeneralisasikan.

Meski harus diakui juga bahwa dalam hal-hal tertentu terjadi persoalan yang dirasakan perempuan dan hal itu berbeda dengan perasan yang dirasakan kaum lelaki, namun tampaknya dalam hal otonomi kedua kelompok responden memiliki kecenderungan untuk menerima ataupun menolak sesuatu secara logis dalam tataran yang sama. Artinya, persoalan otonomi dalam melaksanakan 
peribadatan bukan persoalan yang terkait dengan jenis kelamin, tidak dipersoalkan seseorang itu perempuan ataupun lelaki tatkala dia harus melaksanakan ibadah keagamaan.

Implikasi dari hal tersebut adalah, tidak ada batasan bahwa hanya lelaki ataupun hanya perempuan yang boleh melakukan ataupun tidak melakukan dengan rasional tertentu. Persoalan otonomi dalam melaksanakan ibadah tampaknya lebih dari itu, melampaui batas fisik, sehingga yang dibicarakan adalah konteks di luar fisik, tetapi rasionalitas dan penerimaan seseorang atas satu perintah ataupun keingingan untuk tidak melaksanakan yang juga didasarkan atas rasionalitas mereka.

Hasil lain yang diperoleh dalam penelitian ini adalah, tidak terbuktinya hipotesis ketiga yang diajukan. Seperti diungkap dalam bagian terdahulu, hipotesis terakhir yang diajukan adalah menguji ada tidaknya korelasi antara usia responden dengan tingkat otonomi siswa dalam melaksanakan ibadah keagamaan.

Pada penelitian yang dilakukan oleh Kohlberg terungkap bahwa tahap otonomi moral dalam diri seseorang dapat tercapai pada usia 16 tahun. Hasil penelitian tersebut secara tidak langsung menegaskan adanya hubungan antara usia seseorang dengan tingkat otonomi moral yang dimiliki oleh seseorang. Pada penelitian lainnya yang dilakukan oleh Maligy terungkap bahwa semakin tinggi usia seorang remaja, maka semakin baik pula persepsinya tentang Tuhan. Penelitian maligy ini sejalan dengan penelitian yang dilakukan oleh Kohlber meski dengan setting yang berbeda.

Selanjutnya Wahyono mengungkap dalam penelitiannya bahwa tingkat penalaran moral responden tempat lokasi penelitiannya tinggi. Penelitian ini juga masih mendukung pernyataan sebelumnya, bahwa ada keterkaitan langsung ataupun tidak langsung antara usia seseorang dengan tingkat otonomi yang dimilikinya.

Hasil yang berbeda dilakukan oleh Idrus dalam penelitiannya yang cenderung menyatakan bahwa responden yang diasumsikan memiliki tingkat otonomi moral yang baik ternyata tidak terbukti. Penelitian tersebut secara tidak langsung mementahkan hasil penelitian-penelitian terdahulu. Pada penelitiannya tersebut, Idrus menggunakan pendekatan secara kualitatif yang berbeda dengan 
penelitian sebelumnya yang menggunakan pendekatan kuantitatif.

Selain itu responden yang diambil juga relatif cukup dewasa, yaitu mahasiswa. Asumsi yang dibangun Idrus dalam penelitiannya adalah, usia mahasiswa adalah di atas rata-rata usia yang dihipotesiskan Kohlberg sebagai batasan usia yang telah mencapai tingkat otonomi yang tinggi, dengan mengambil responden mahasiswa secara tidak langsung batasan usia mereka masuk pada kelompok usia yang memiliki tingkat otonomi dalam persoalan perkembangan moral.

Adanya variasi hasil ini membuka peluang untuk dilakukan repilikasi, dan hasil penelitian replikasi ini tampaknya mendukung penelitian yang terakhir. Dari hasil perhitungan dengan menggunakan korelasi, diperoleh harga r 0,0060. Harga tersebut tampaknya jauh di bawah batas penerimaan $\mathrm{r}$ pada taraf signifikansi $5 \%$. Dengan begitu penelitian ini menolak hipotesis alternatif yang diajukan dan menerima hipotesis nihil yang ada.

Dari hasil penelitian ini secara nyata dapat dideskripsikan bahwa perkembangan otonomi keagamaan yang dimiliki oleh seseorang tidak tergantung pada usia yang berangkutan. Pada kenyataannyanya dapat dijumpai pelbagai kasus penyimpangan terhadap pelaksanaan ibadah yang dilakukan justru oleh mereka yang memiliki usia di atas usia batas yang telah disepakati oleh Kohlberg. Mungkin saja hal itu terjadi, jika pada kasus-kasus khusus yang tidak terkait dengan agama secara langsung, dan objek kajian Kohlberg tentang pertumbuhan moral memungkinkan menerima asumsi yang dibangun tersebut. Namun untuk persoalan ibadah keagamaan, otonomi tidaknya seseorang tergantung banyak faktor, dan itu begitu relatif. Senyatanya penelitian ini membuktikan bahwa tidak ada hubungan yang signifikan antara usia seseorang dengan tingkat otonomi yang dimilikinya. Dengan begitu semakin tinggi usia seseorang tidak menjamin yang bersangkutan memiliki otonomi dalam pelaksanaan ibadah keagamaannya. Sebaliknya mereka yang berusia muda tidak berarti tidak memiliki otonomi yang baik dalam pelaksanaan ibadah. 


\section{Keimpulan}

Dari jumlah responden yang ada, ternyata otonomi dengan model "budak" untuk siswa SMU UII sebanyak 6 orang $(6,1 \%)$, otonomi dengan model "pedagang" sebanyak 59 orang $(60,2 \%)$ dan sisanya sebanyak 33 orang $(33,7 \%)$ termasuk dalam kelompok "sang arif".

Dengan menggunakan formula t test pada model pooled variance estimate harga t diperoleh sebesar -1,29, sedangkan dengan menggunakan model Separate Variance Estimate harga t sebesar 1,31, keduanya tidak signifikan pada taraf signifikansi $5 \%$. Dengan begitu disimpulkan tidak ada perbedaan antara siswa perempuan dan siswa lelaki tentang otonomi mereka dalam melaksanakan ibadah keagamaan.

Hasil analisis varian dua jalur diperoleh harga main effect sebesar 1,556, harga ini tidak signifikan pada taraf signifikansi $5 \%$. Dengan begitu disimpulkan tidak ada perbedaan tingkat otonomi dalam melaksanakan ibadah keagamaan di antara siswa SMU UII dengan latar belakang pendidikan sebelumnya yang berbeda. Sementara, hasil perhitungan korelasi diperoleh harga $r$ sebesar 0,0060 , seperti juga harga $\mathrm{t}$ ataupun $\mathrm{F}$ pada analisis varian dua jalur, harga $r$ ini juga tidak signifikan, sehingga penelitian ini menyimpulkan tidak ada korelasi antara usia dengan tingkat otonomi dalam melaksanakan ibadah keagamaan di antara siswa SMU UII.

\section{Daftar Pustaka}

Al-Qur'an dan Terjemahannya. 1994. Yogyakarta: Universitas Islam Indonesia.

Basyir, Ahmad Azhar. 1993. Refleksi Persoalan Keislaman: Seputar Filsafat, Hukum, Politik dan Ekonomi. Bandung: Mizan.

Ensiklopedi Hukum Islam. 1997. Jakarta: PT. Ichtiar Baru Van Hoeve. Idrus, Muhammad. 1998. Otonomi Moral Keagamaan Mahasiswa Fakultas Tarbiyah UII. Tesis pada PPS IKIP Yogyakarta. Tidak diterbitkan.

Kohlberg, Lawrence. 1976. Moral Stages and Moralization: The Cognitive-Developmental Approach. dalam Moral Development and Behavior: Theory, research, and social issues. Thomas Lickona, Editor. Halaman 31-53; New York: Holt, 
Rinehart ans Winston.

Kohlberg, Lawrence. 1995. Tahap-tahap Perkembangan Moral. John de Santo dan Agus Cremers SVD (Penterjemah). Yogyakarta: Kanisius.

Maarif, A. Syafii. 1995. Membumikan Islam. Yogyakarta: Pustaka Pelajar.

Madjid, Nurcholish, 1994. Pintu-pintu Menuju Tuhan. Jakarta: Paramadina.

Nasution, Harun. 1986. Teologi Islam: aliran-aliran sejarah analisa perbandingan. Jakarta: UI Press.

Nizar, Hayati. 1992. Pemahaman Nilai-nilai Keagamaan Oleb Remaja di Sumatera Barat. Disertasi Doktor. Fakultas Pascasarjana dan Pendidikan Doktor IAIN Sunan Kalijaga Yogyakarta.

Popham, J.W. and Sirotnik, K.A. (1971. Education Statistik : Use and Interpretation. New York: Harper \& Row Publisher.

Shihab, M. Quraish. 1994. Lentera Hati: Kisab dan Hikmah Kehidupan. Bandung: Mizan.

Solomon, Robert C. 1984. Etika Suatu Pengantar. Terjemahan R. Andre Karo-karo. Jakarta: Erlangga.

Stark, R. dan C.Y Glock. 1988. Dimensi-dimensi Keberagamaan, dalam Agama: Dalam analisa dan intpretasi sosiologis. Roland Robertson, ed. Penerjemah Ahmad Fediyani Saifudin. Hal 291-302. Jakarta: Rajawali Press.

Tjahyadi, Lili S.P. 1991. Hukum Moral, ajaran Immanuel Kant Tentang Etika dan Imperatif Kategoris. Yogyakarta: Kanisius. 